\title{
COALITION FORMATION IN BELGIUM
}

\author{
From exceptional complexity \\ to regime breakdown?
}

Lieven De Winter and Patrick Dumont

\subsection{Introduction}

The New York Times reported that on Sunday January 23, 2011, 34,000 Belgians marched the streets of Brussels under the banner "Shame. No government, great country" (Castle, 2011). Defying the normal conventions of protest politics to try to get rid of a government, this was a public outcry to the political class to finally form a government, 255 days after the May 13, 2010 general elections. Belgium was well on the way to break the world record of government formation duration, with 354 days record hitherto held by Cambodia. Eventually, with 541 days, that record was pulverized by the installation of the Di Rupo government on December 5, 2011.

In West European comparative perspective, Belgium is indeed an exceptional case in terms of coalition formation: high or even record values are reached regarding the classic determinants of government formation complexity (such as number of players, uncertainty and information scarcity), the structure and features of the cabinet formation process (e.g. institutional constraints, long formation duration) and its outcomes ("irrational" coalition composition, extensive coalition agreements). These core features of the bargaining process affect the life of coalitions, in terms of government duration, intra-cabinet conflictuality, policy inertia and ineffectiveness.

This chapter presents the Belgian case on all these coalition formation and functioning core variables in comparative West European perspective. We find that on most of these independent and dependent variables of the chain of coalition formation (see Figure 7.1), Belgium scores record-breaking values, or at least is one of the top three "performers".

Our theoretical framework draws on the comparative projects of Strøm, Müller \& Bergman that by now empirically embrace the 1945-2019 period in 


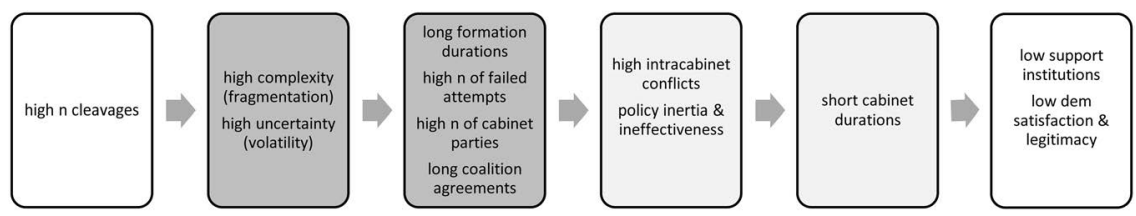

FIGURE 7.1 Cabinet formation, determinants and effects

Western as well as Eastern and Central Europe (hereafter C1, C2, C3 and C4) ${ }^{1}$ and updates and extends our previous work on the Belgian case. We also investigate whether these exceptional government formation features impact citizens' trust in politics and satisfaction with democracy, eroding the legitimacy of the wider political system and fostering its disintegration.

\subsection{Bargaining complexity and information uncertainty, causes and consequences}

We define bargaining complexity as the difficulty of finding a coalition of parties that would make a viable coalition government. Complexity increases when actors involved in the formation of a government face a high number of viable coalition outcome "resolutions". These outcomes comprise (1) the partisan composition of the coalition; (2) the results of policy negotiations, usually contained in a coalition policy agreement and (3) the distribution of ministerial portfolios and other key positions (e.g. chairpersons for the assemblies, EU Commissioner). Obviously, ceteris paribus, the fragmentation of the parliamentary party system boosts bargaining complexity, in an exponential manner. ${ }^{2}$

After the 1999 elections, which led to a new peak in the fragmentation of seats among parties in parliament, no less than nine different coalitions were at the same time clearing the following formal and informal constraints: (1) winning more than $50 \%$ of seats in the federal parliament; (2) based on a majority of MPs in each language group and (3) symmetrically composed, i.e. each linguistic component of a "party family" was part of the potential coalition (Dumont, 2011). However, some of these informal composition constraints have been relaxed in most of the governments formed since 1999. Thus, in 2019, with 4,095 coalitions numerically possible given the parliamentary seat distribution $(2,021$ of which are winning), bargaining complexity has probably never been higher.

Research on coalition bargaining has highlighted a second factor which is likely to delay cabinet formation duration: information uncertainty. Rather than being involved in a bargaining game where all players have complete information over the preferences and strategies of the others, in practice, party leaders face a much messier reality. These actors are often not transparent in their preferences, and change their preferences during the formation. Elections are being particularly disruptive in terms of vital information (Diermeier \& van Roozendaal, 1998); whereas party leaders gradually learn about preferences and 
strategies of government partners and opposition parties in day-to-day legislative work, parties come to elections with new platforms and demands; furthermore, they undergo changes in size in accordance to their electoral performance; in addition, the heat of the campaign may have polarized positions and (internal) rivalries and disappointing results may also provoke a change of leader to represent the party in government formation talks.

Especially after high-volatility elections, uncertainty would plausibly be high. In periods of high electoral stability, a party can be more easily be persuaded to enter a coalition (Strøm, 1990): all else equal, the less party leaders have to worry about possible repercussions in future elections, the more willing they will be to reach an (coalition) agreement, which under other circumstances would have appeared too risky. In periods of high electoral competitiveness, the bargaining situation is made more complex by the fact that the ratio of instant office rewards to deferred electoral costs may be lower or more uncertain, given the long-term trend that governing parties increasingly tend to lose more votes than opposition parties (Narud \& Valen, 2008). Thus, when parties tend to focus on vote-seeking rather than office-seeking strategies (Strøm \& Müller, 1999), one would expect more bargaining rounds and longer periods of negotiation. Finally, Strøm (1994) also argues that party preferences and strategies may also not be stable throughout the formation process. Thus, although a longer formation process may be needed to gather new information, its very length may also bring new uncertainty by causing preference changes within and across parties at the bargaining table.

Information uncertainty is thus conceptualized separately from bargaining complexity. In a three-party system where any two-party coalition is a winning formula, it will be more difficult, ceteris paribus, to form a government right after an election than midway in the legislative term.

The interaction of high bargaining complexity and high information uncertainty leads to the most difficult circumstances in which coalition governments are to be formed. In this chapter, we analyze whether this core relationship is true, concentrating on the Belgian case in comparative perspective. Figure 7.1 depicts how we extend our analysis from this initial link between complexity and uncertainty with coalition formation (in dark grey) to the study of coalition governance and stability (in light grey), and to the likely societal causes and consequences (in white) of the often assumed exceptionally difficult job of forming and maintaining governments in Belgium.

Our expectations are, in line with the existing literature, that high party fragmentation results from a high number of societal cleavages. Combined with the uncertainty of (especially disruptive) elections, this bargaining complexity would lead to more failed attempts to reach the final coalition solution and thus require longer formation durations (De Winter \& Dumont, 2008). In turn, we expect that high complexity due to party system fragmentation will also be associated with a high number of coalition parties that end up governing. The more parties in government, the more likely these will have different policy preferences 
and incentives to deviate from what was discussed at the time of government formation or even to leave the coalition once their preferred legislation has been passed. To avoid such "opportunistic" behavior, formateurs will seek to build credible commitments among parties in the form of comprehensive coalition agreements. The comprehensiveness of these documents, and therefore also their size, is likely to increase with the level of distrust among actors involved. Since distrust is linked to information uncertainty, we thus expect that in terms of the functioning of coalition, both high bargaining complexity and uncertainty will also lead to, ceteris paribus, longer coalition agreements (see Müller \& Strøm, 2008). We document these links in the following section of the chapter.

Moving to the right hand side of Figure 7.1, and to the third section of this chapter, we argue that, because even comprehensive coalition agreements are "incomplete contracts" and because exogenous events may force coalition partners to take decisions on issues that were not anticipated at the time of government formation, the large number of coalition parties - and its related greater array of policy preferences - will lead to higher intra-cabinet conflictuality and/ or policy inertia and ineffectiveness, eventually making for shorter cabinet duration. Finally, in the conclusion, we investigate whether these latter three dysfunctions in particular could spill over into the political culture, producing low trust in political institutions, dissatisfaction with the functioning of democracy, erosion of the legitimacy of the entire political system, fostering its instability and even potentially triggering its breakdown.

\subsection{Cleavages, party fragmentation, multilevel politics and electoral volatility}

Our empirical analysis puts the Belgian case in comparative perspective, focusing on Western Europe. ${ }^{3}$ Given that party system fragmentation is a crucial determinant of bargaining complexity, the period under study starts in 1978, with the split of the last traditional unitary party, the Belgian socialists (PSB-BSP). It ends with the formation of the (exceptional) De Croo seven-party coalition on October 1, 2020. Throughout the chapter, our empirical analyses mostly draw on the data that was collected with the framework of not only C1, C2 and C4 (2021) but also other comparative datasets, some of which may refer to a longer time period or, on the contrary, not cover the full 1978-2020 time span.

As seen earlier, the distribution of seats between parties has a direct effect on the total number and the number of potential coalitions that would reach more than $50 \%$ of seats in parliament and thus make for a viable, majority-supported government. Laakso and Taagepera's (1979) Effective Number of Parliamentary Parties (ENPP) is the operationalization most often used in comparative politics to measure party system fragmentation. It takes into account the number and the size of parliamentary parties and thus reflects the bargaining complexity concept introduced earlier. In the period under consideration, Belgium is the record holder of the average party system fragmentation measured by 
Laakso-Taagepera's ENPP (in the Chamber of Representatives). It also holds the highest level of fragmentation ever recorded in Western Europe: after the 2019 elections its ENPP peaked at 9.7.

Another way of looking at the difficulty of forming a coalition is to look at the relative size of the largest party in parliament. Across Western Europe, that party is indeed expected to play a prime role in coalition formation. Sometimes the constitution recognizes the leader of that party the right to "make the first move" (Bäck \& Dumont, 2008), that is, to invite other parties to negotiate a coalition together. The smaller the largest party, the more contested its status as first formateur, and the more partners it will need to coalesce with to reach a majority, thereby making coalition formation more difficult. Throughout the period 1978-2014, Belgium was the Western European country with the lowest average number of parties that received more than $15 \%$ of the vote in an election and thus had the smallest number of "major parties" (Siaroff, 2019: Table 2.1), and that in 1999 , even its largest party had not reached that $15 \%$ threshold. ${ }^{5}$

What brings about this high level of party system fragmentation? Aside from the effect of electoral systems (Duverger, 1950), the most pertinent determinant of the format of party systems is the number of cleavages in society, as defined by Lipset and Rokkan (1967). Unfortunately, to our knowledge, there is no authoritative comparative research on the number of relevant cleavages in West European democracies. According to Lijphart's (1999) subjective and unsystematic attempt, Belgium is one of the very few plural, in the sense of deeply divided, West European countries. However, Taagepera and Grofman (1985) claim that there does exist a direct and simple mathematical link between the number of cleavages and the ENPP. The formula would be $E N P P=n$ cleavages +1 . If they are right, with an ENPP fluctuating between 6.8 (1978) and 9.7 (2019), no less than six to eight cleavages would have been relevant in Belgium in the last 40 years.

This seems hard to reconcile with common ways of counting cleavages in the Belgian polity (De Coorebyter, 2008), which records three traditional cleavages: the first being religious (Church/State), the second socioeconomic (left-right) and the third linguistic (Flemish vs francophones). The different components of what makes for a more recent cleavage in Western Europe, summarized as the Green-Alternative-Libertarian vs Traditionalist-Authoritarian-Nationalist divide by Hooghe et al. (2002), do also need to be taken into account. And, rather than counting the linguistic cleavage as one of those present in the Belgian party system as a whole, one could consider the latter as made of two different party systems (one Flemish and one Francophone one), each with its own cleavage constellations. In the Francophone party system, we would find the Church/ State (or liberal vs traditional values opposition of the GAL-TAN cleavage), the economic left-right and the environment vs productivism cleavages. The cosmopolitan vs nativism cleavage is not politicized given the absence of a successful far right francophone party, nor the Flemish vs francophone divide as all francophone parties endorse the institutional status quo regarding devolution. In the Flemish party system, we find the same cleavages as in the South but we need 
to add the Flemish vs francophones cleavage (ranging from moderates to separatists, which can also be seen as a "super cleavage" over the "Belgian system", see below) and the cosmopolitan vs nativism divide politicized mostly by the Vlaams Belang. Altogether then we would arrive at eight cleavages politicized in the Belgian party systems: five in Flanders and three in Wallonia.

In addition to its effect on the number of cleavages that are pertinent for the representation of parties in the federal parliament, Belgium's linguistic community divide has also led to the construction of a multilevel political system. The latter has not only increased complexity of reaching an agreement at the bargaining table through the higher number of parties that is necessary to build a federal government (at least four) but has also increased information uncertainty. Through constitutional reforms since the 1970s, leading to the regionalization of most federal competences and the transfer of most public resources, the lack of hierarchy of norms and the holding of direct elections to regional parliaments, the regional and community level is now considered at least as important as the federal level (Reuchamps et al., 2017).

The addition of elections at the regional level, the territorial unit where parties are organized, with the formation of regional and community executives at stake, has triggered more information uncertainty for cabinet formation and maintenance at the federal level. First, in those regional elections, the main parties in each linguistic community have from 1995 onwards waged a fierce competition to become the largest party in seats in their regional parliament. Contrary to the federal level, the King plays no constitutional role in regional government formation; hence, the largest party is the natural formateur at that level. This battle for regional leadership has enhanced volatility, especially in Flanders where no less than four parties have become the leader in seats in one decade. Second, party leaders who negotiate for their party at both the regional and federal level have by now been socialized in this new, regionalized context where a political career in one's own region is equally prestigious as one at the federal level. The gradual emergence of this new generation caused misunderstandings and mistrust among long-standing coalition negotiators in the 2007 government formation. Third, the empowerment of regional institutions and actors have contributed to the drifting apart of the Flemish and Francophone civil societies allowing the Flemish nationalists to transform the nebulous thesis of segmented pluralism (Lorwin, 1971) into the deception of "two democracies", two nations growing apart but held prisoner in an artificial state. ${ }^{6}$ Fourth, regional elections have not only contributed to building regional identities but have also tended to radicalize party positions on the linguistic/community divide as leaders only appeal to voters from their community. The 2007 government formation was again a case in point but, by the 2019 elections nearly half of the Flemish voters opted for the two parties (N-VA and VB) that strive for Flemish independence, and thus the demise of the Belgian political system/state. When anti-Belgium-system parties become relevant in coalition bargaining at the federal level, uncertainty is bound to rise as mainstream parties are unlikely to know their true objectives and strategies. For instance, the N-VA, considered by about all other Flemish parties as 
"coalitionable", 7 could in principle profit from at least two diverging strategies: either joining a federal coalition in exchange for major institutional concessions toward more Flemish autonomy, or, sabotaging for months the formation of a coalition without them, thus showing that the Belgian (federal) system is ungovernable and thus should be abandoned all together.

In addition to increased uncertainty at the federal bargaining table when regional elections have been organized on the same day as the federal elections (1995, 1999 and 2019) and government formation at different levels were interrelated, regional elections also made federal coalition maintenance (and following federal coalition formation) more difficult when the elections were not synchronized: heated campaigns among parties at one level affected the internal cohesion and work of coalition governments at another level, and the formation of coalitions with different partners across levels both accentuated coordination problems between interregional and federal decision-making (Deschouwer, 2012), eventually also blurring responsibility given that often all parties were in power at least at one level, a point we come back to later when exploring the consequences of Belgium's complex governance system on public opinion.

In terms of information uncertainty then, even though overall electoral volatility in Belgium was lower in the period than where the old party regime was blown away by newcomers, it has been higher than the West European average (Caramani, 2015; Siaroff, 2019) with peaks in 1981, 1991, 1999, 2003, 2010 (and 2019) followed by elections with greater stability. Also, even if it was not as abrupt as in some other countries, the electoral decline of mainstream parties (Christian democrats, socialists and liberals) was dramatic, from a combined share of votes of $78 \%$ in 1978 to $45 \%$ in 2019 . This means that especially for those parties, which were still the core actors of all coalition governments in the period, government participation has increasingly become a serious electoral risk, often paid cash in votes at the next elections. As a result, mainstream parties have become ever more cautious when underwriting compromises in the bargaining process.

Finally, in addition to party leaders becoming increasingly socialized and politicized in separate arenas, information certainty increased due to changes of party leaders during periods of government negotiations. Comparative research shows that short experience as a party leader results in lengthier and more failure-ridden bargaining periods (Ecker \& Meyer, 2020). For instance, at the time of formation of the De Croo government in 2020, only two of the eight party leaders who signed the coalition agreement had led their party in the 2019 electoral campaign. ${ }^{8}$

\subsection{Formation process and outcomes features}

The previous section has shown that Belgium was exceptional in terms of bargaining complexity in the period under study, and that information uncertainty had also been high because of the relevance of the linguistic/community divide and the need to form federal coalitions with parties that compete (mostly) within their own community. A first consequence of the combined effect of those 
characteristics is its record-long government formation duration: for postelection cabinets in Western Europe 1945-2016, it took on average 104 days, a record held together with the Netherlands. However, the 2019-2020 government formation lasted 493 days, so Belgium would hold the European record of average duration of formation, as the Rutte III cabinet of 2017 took "only" 225 days to form. In any case, the European record of the longest single formation is also Belgian, with the infamous 541 days to form the Di Rupo government (2010-2011).

Simply put, this exceptionally long formation process is due to the large number of failed bargaining attempts. Often a set of parties start bargaining, but after some weeks or months, they realize that no coalition policy compromise is possible. Belgium holds the West European record in this regard as well, with close to three failed attempts before succeeding in forming a government in the 12 post-electoral formations since 1978. It took for instance no less than eight attempts to arrive at a viable coalition formula and coalition agreement for the Di Rupo coalition (2011-2014), and even 13 attempts for the 2019-2020 formation (Sägesser, 2020).

Belgium is the record holder on those two features reflecting the difficulty of the formation process because the combined effect of the bargaining complexity and information uncertainty factors described earlier largely determine the types of formation outcomes those processes would lead to. One of those outcomes is the size of the cabinet in terms of number of coalition partners, for which again Belgium scores highest in Western Europe: considering coalition cabinets only, the average number of cabinet parties in Belgium since 1970 sits at 4.54, the highest, with Italy and Finland coming second and third, with, respectively, 4.32 and 4.07 cabinet parties.

Another outcome, and additional cause for long formation duration, is the level of care that partners give to the policy agreement that seals their deal. Coalition agreements are the result of negotiations where each partner comes with its own policy demands and are likely to require several sessions to arrive at compromises, especially when a large number of sometimes quite ideologically distant parties are at the bargaining table. In the 1945-1998 period, Belgium had the longest government agreement (Martens VII in 1988 - known as Martens VIII in Belgium's usual counting - 43,600 words), and also the highest average in Western Europe (14,180 words). Even though the Di Rupo and Michel agreement surpassed that earlier record (53,000 and 57,100 words, respectively), in the following period some countries started drawing even longer agreements, and Belgium had some surprising short ones. Taking this period as a whole, Belgium would now rank third in Western Europe with over 20,000 words for 24,000 words for Germany the new record holder. ${ }^{9}$

\subsection{Government formation, outputs, outcomes and their effectiveness}

Coalitions that contain many parties are delicate constructions that take a long time to form but can be easily be destroyed. Despite comprehensive agreements, programmatic disputes between parties are usually at the heart of intra-cabinet 
conflicts during the life of government (Damgaard, 2008). Also in Belgium the main reason for cabinet termination is conflicts between coalition parties (19 out of 43 governments in the 1946-2019 period). In terms of actual government duration, Siaroff's (2019) data put Belgium second after Italy (with 13 months and 17 months, respectively), while C4-data rank Finland second and Belgium third.

Long formation durations and short-lived governments do not give much time for government to prepare, pass and implement effective policies. Dandoy and Terrière, in this book, investigate the growing occurrence and length of caretaker cabinets in Belgium, which are (or at least are expected to be) relatively impotent governments given their restricted decision-making capacity (Ecker \& Meyer, 2020). But even for fully empowered and thus viable governments, the need to contain coalition conflicts and the difficulty to change the policy status quo have had consequences for effective decision-making and policy innovation.

The high number of coalition partners has led to the adoption of a wide variety of conflict solving mechanisms, some of which are time consuming (Kerncabinet, confessionals, party summits, cabinet committees and inter-cabinet working groups, etc., see De Winter, Timmermans, \& Dumont, 2000; De Winter \& Dumont, 2021) and slow down decision-making. Sometimes compromises are only found by paying off the conflicting demands of all coalition parties, by awarding extra expenditures to each party "clientele" (cfr. the mega deals, "pacts" concluded on the denominational, economic and institutional divide). This method became burdensome for public finances since the economic recession of the late 1970 s.

Coalitions counting usually four to six parties tend to write coalition policy agreements in which, for each and every policy issue, a coalition compromise position is formulated that is situated somewhere close to the average positions of coalition parties. In Belgium, this has often resulted in a position that is close to the one of the median position of parties represented in parliament: that of the (Flemish) Christian democrats (De Winter \& Dumont, 1999). An exception was the Verhofstadt I six-party coalition that adopted a different, generalized exchange (uitruil) strategy, due to the large programmatic heterogeneity of the liberal, socialist and Green party families (Dumont, 2011). The parties followed the logic of "policy territories", where liberal views were mostly reflected in the tax reform plans, socialists influenced mostly the social policy areas, and Greens could make their imprint on transportation and energy, and each party family received ministerial remits accordingly. Overall, the much more usual logic was to find a median compromise for an overall centrist coalition, which led to policies that were not only close to the Christian democrats' habitual positions but also to those of the previous governments, thus barely moving from a status quo position. On the one hand, this logic assured policy stability, but on the other hand, it led to policy inertia, and thus suboptimal effectiveness. 
In fact, the difficulties of forming and maintaining Belgian coalition governments have affected the effectiveness of their policy outputs and outcomes. A general longitudinal and comprehensive indicator of good governance is a state of healthy public finance, in terms of the size of the national public debt (Tarek \& Ahmed, 2017). In 1993, in the run up to the Maastricht Treaty conversion norms, Belgium public debt reached an unedited Eurozone record of nearly $140 \%$ of GDP, beating even Italy. Its public debt to the 1989-2019 period stands at $110 \%$, behind Italy $(113 \%)$ and Greece $(121 \%) .{ }^{10}$ Regarding the size of the shadow economy (undeclared economy in percentage of GDP), Belgium was bypassed in 2000 and 2016 by only three West European countries: Portugal, Italy and Greece. ${ }^{11}$ Finally, rankings provided by Transparency International on the perception of (political) corruption show that until 2000, Belgium was perceived to be among the most corrupt country in the EU, and clearly the most corrupt amongst countries that do not belong to Southern Europe (De Winter, 2002). However, since 2001 the country's position gradually improved. In 2011 and 2019, Belgium was surpassed by not only Portugal, Italy, Spain and Greece but also by Ireland and France.

A contemporary sectorial snapshot indicator of good governance is the success of a country fighting the COVID-19 pandemic. There is some discussion about the validity of the figures published by national governments in terms of cases detected, successfully treated and mortal casualties. One of the most comprehensive measure is the "excess deaths" or "excess mortality rates", ${ }^{12}$ i.e. the number of deaths per 1,000 inhabitants from all causes during a crisis above and beyond what we would have expected to see under "normal" conditions (Checchi \& Roberts, 2005). Regarding the peak months (March and April) of the first wave of the pandemic, Belgium had the highest excess rates after Spain and Italy, compared to the 2016-2019 averages. ${ }^{13}$ Thus, it does not come as a surprise that Belgians were little satisfied (57\%) with the measures the government had taken so far (end of April 2020): only Italians, Frenchmen and Spaniards were less satisfied. ${ }^{14}$

Regarding citizens classic political support attitudes (van Ham \& Thomassen, 2017), however, generally Belgium scores around West European averages. The nine European Social Surveys (2002-2018) indicate that Belgians have comparatively $(E U)$ a bit more than average trust in politicians and in political parties but a bit less trust in parliament, the legal system, the police and the national government. Also satisfaction with the way democracy works in one's country is below average. Thus, we do not find really "exceptional" averages in the longitudinal comparative perspective. However, this does not exclude extreme low values for some indicators at a particular moment. For instance, in the aftermath of the Dutroux and dioxin affairs, satisfaction with democracy had dived under the traditionally pathologically low score of $20 \%$ of Italy. But it fully and swiftly recuperated toward a more average position in Western Europe. ${ }^{15}$

Finally, support for political actors, institutions, processes, policies, principles, ideas and values, etc., are all components of the overarching but fuzzy concept of "political legitimacy", the degree of how power is used in ways that 
citizens consciously accept. There is a general presumption that a legitimacy crisis may trigger the replacement of a dysfunctional regime by an unaccepting society (van Ham \& Thomassen, 2017). The concept is, however, hard to measure (Weatherford, 1992). To our knowledge, only Gilley (2006) made an empirical, multidimensional study of state legitimacy in the late 1990s and early 2000s for 72 states. Gilley (2006, p. 501) defines legitimacy as a degree: “a state is more legitimate the more that it is treated by its citizens as rightfully holding and exercising political power". Amongst West European democracies, Belgium enjoys the lowest degree of state legitimacy except for Italy and Greece (Gilley, 2006, p. 514).

Thus, overall, we do not find much of a link between the levels of institutional performance and popular political support in Belgium (Magalhães, 2017). Conjecturing that this lack of an expected relationship is part and parcel of Belgian exceptionalism would probably go a bridge too far however.

\subsection{Discussion and conclusion: a truly exceptional and explosive case}

Despite truly exceptional and potentially explosive societal characteristics (number of cleavages and the linguistic/community divide in particular) that lead to extremely difficult cabinet formations and maintenance of governing coalitions, the degree of the Belgian "malgoverno" (Heylen \& Van Hecke, 2008) as reflected by political instability or policy outputs and outcomes need to be relativized when compared with other West European countries. Some Belgian political personnel "genie" might be credited for that better-than-expected performance given preexisting conditions. But the state of domestic politics and the economic performance of other European countries obviously also affect the relative ranking of Belgium on corresponding indicators. In addition, Belgium also had some "lucky" episodes where policy inertia turned out to be preferable to actual choices due to international economy circumstances (Albalate \& Bel, 2020). ${ }^{16}$ But those rare episodes could only be seen as positive in retrospect.

Whether because the Belgian "political genie" is also efficient in terms of communication, because of low clarity of responsibility triggered by the lack of transparency of a complex system or out of mass public resignation and apathy, we do not find much of a relationship between the less than optimal governance indicators, trust in institutions, satisfaction with democracy and legitimacy.

Up until now, the blatant legitimacy deficit has not spilled over into citizen behavioral revolt, by a vote empowering antiestablishment parties or mass demonstrations. However, it may just become impossible to form a federal government in the near future. At the time of writing this chapter, most Flemish parties call for further devolution after the 2024 elections, while most francophone parties prefer the status quo. In addition to this institutional agenda already anchored on the 2024 political agenda, formulating a coalition compromise on the unavoidable austerity policies for restoring the economy costs 
of the anti-Covid emergency measures may be an unsurmountable hurdle for any coalition formula. In addition, it is not unlikely that at the 2024 federal and regional elections, the separatists parties (VB, N-VA) win a majority of the seats in the Flemish parliament, forming an independence-seeking Flemish government, while at the same time being able to sabotage the formation of a federal government. A new prolonged formation impasse may show that the centrifugal Belgian federal system does not function anymore as a régime capable of legitimately governing "two separate democracies", and should be dumped all together.

\section{Notes}

1 C1 = Müller W.C. \& Strøm, K. (Eds.). (2000). Coalition Governments in Western Europe. Oxford: Oxford University Press; C2 = Strøm, K., Müller, W. C., \& Bergman, T. (Eds.). (2008). Cabinets and coalition bargaining: the democratic life cycle in Western Europe. Oxford: Oxford University Press; C3 = Bergman, T., Ilonszki, G., \& Müller, W. C. (Eds.) (2020). Coalition Governance in Central Eastern Europe. Oxford: Oxford University Press; C4 = Bergman, T., Bäck, H., \& Hellström, J. (Eds.). (2021). Coalition Governance in Western Europe. Oxford: Oxford University Press.

2 The number of solutions equals $2^{n}-1$, where $n$ stands for the number of parties represented in parliament.

3 We exclude East and Central European democracies given their still unconsolidated party system. Also, we exclude Malta (for its lack of coalition cabinets), France (semi-presidential system), Cyprus (presidential system) and European microstates. We further exclude Switzerland, a country where the four main parties agreed in 1959 on a more or less proportional "magic formula" that would include them all in subsequent governments.

4 See: https://www.tcd.ie/Political_Science/people/michael_gallagher/ElSystems/Docts/ ElectionIndices.pdf.

5 Putting those two indicators together, Siaroff (2019) developed an Index of Coalition Difficulty (ICD) that combines the ENPP with the size in seats of the largest party. The higher this value, the assumed greater the challenge of forming a government. Again, Belgium has the highest average for Western Europe in the period under study.

6 Most intra-Belgian comparisons actually do not reveal sharp differences in social and political attitudes between Flemish and Walloons (Billiet, Maddens \& Frognier, 2006).

7 And the latter increasingly considers the Vlaams Belang as a potential government partner: in 2019, the formateur party N-VA invited first theVlaams Belang for coalition talks that lasted two months in the regional government formation process before turning to the mainstream parties.

8 The coalition is made of seven parties but Ecolo has two co-presidents.

9 The Prodi II agreement in 2006 in Italy and the Bettel II in 2018 in Luxembourg counted more than 80,000 words. Regarding the average size of the coalition agreements, Germany is now the record holder (the latest two Merkel governments had much longer agreements than earlier ones, topping each at more than 60,000 words), followed by Austria (the 2017 Kurtz agreement also had close to 60,000 words).

10 See: https://tradingeconomics.com/portugal/government-debt-to-gdp

11 See: https://www.imf.org/en/Publications/WP/Issues/2019/12/13/Explaining-theShadow-Economy-in-Europe-Size-Causes-and-Policy-Options-48821

12 Each demise in pensioners homes (the largest sector of casualties) is usually counted as a COVID-19 victim, which is certainly an overestimation and more inclusive than the way casualties are counted in most other West European countries.

13 See: https://ec.europa.eu/eurostat/statistics-explained/images/5/5c/Table_1_Excess_ mortality_indicator_Jan21_update2.png 
14 https://www.europarl.europa.eu/at-your-service/en/be-heard/eurobarometer/ public-opinion-in-the-eu-in-time-of-coronavirus-crisis

15 See: https://www.gesis.org/en/eurobarometer-data-service/search-data-access/eb-trendstrend-files/list-of-trends/democracy-satisf

16 Albalate and Bel (2020) show that the long 2010-2011 formation period led to better GDP per capita growth than what would otherwise have been expected.

\section{References}

Albalate, D., \& Bel, G. (2020). Do Government Formation Deadlocks Really Damage Economic Growth? Evidence from History's Longest Period of Government Formation Impasse. Governance 33(1): 155-171.

Bäck, H. \& Dumont, P. (2008). Making the First Move. A Two-Stage Analysis of the Role of Formateurs in Parliamentary Government Formation. Public Choice 135(3-4): 353-373.

Bergman, T., Bäck, H. \& Hellström, J. (Eds.) (2021). Coalition Governance in Western Europe. Oxford: Oxford University Press.

Bergman, T., Ilonszki, G., \& Müller,W. C. (Eds.) (2020). Coalition Governance in Central Eastern Europe. Oxford: Oxford University Press.

Billiet, J., Maddens, B., \& Frognier, A. P. (2006). Does Belgium (Still) Exist? Differences in Political Culture Between Flemings and Walloons. West European Politics 29(5): 912-932.

Caramani, D. (2015). The Europeanization of Politics. The Formation of a European Electorate and Party System in Historical Perspective. New York, NY: Cambridge University Press.

Castle, S. (2011) Belgians Press Politicians to Form Government (a Lack of One, That Is). New York Times, January 312011.

Checchi, F., \& Roberts, L. (2005). Interpreting and Using Mortality Data in Humanitarian Emergencies. Humanitarian Practice Network, Paper Nr. 52.

Damgaard, E. (2008) Coalition Termination. In K. Strøm, W. C. Müller, \& T. Bergman (Eds.) Cabinets and Coalition Bargaining: The Democratic Life Cycle in Western Europe. Oxford: Oxford University Press, pp. 301-326.

De Coorebyter, V. (2008). Clivages et partis en Belgique. Courrier hebdomadaire du CRISP 2000(15): 7-95.

Deschouwer, K. (2012). The Politics of Belgium. Basingstoke: Palgrave Macmillan.

De Winter, L. (2002). Political Corruption in Belgium. In M. Bull \& J. Newell (Eds.). Corruption in Contemporary Politics. London: Macmillan, pp. 93-105.

De Winter, L., \& Dumont, P. (2008). Uncertainty and Complexity in Cabinet Formation. In K. Strøm, W.C. Müller, \& Bergman, T. (Eds.) Cabinets and Coalition Bargaining: The Democratic Life Cycle in Western Europe. Oxford: Oxford University Press, pp. 123-158.

De Winter, L., \& Dumont, P. (1999). Belgium: Party System(s) on the Eve of Disintegration? In Broughton, D., \& Donovan, M. (Eds.) Changing Party Systems in Western Europe. London: Pinter, pp. 183-206.

De Winter, L., \& Dumont, P. (2021). Belgium: From Highly Constrained and Complex Bargaining Settings to Paralysis?. In Bergman,T., Back, H., \& Hellström,J. (Eds.) Coalition Governance in Western Europe. Oxford: Oxford University Press, pp. 81-123.

De Winter, L., Timmermans, A., \& Dumont, P. (2000). Belgium: On Government Agreements, Evangelists, Followers and Heretics. In W.C. Müller \& K. Strøm (Eds.) Coalition Governments in Western Europe. Oxford: Oxford University Press, pp. 300-355.

Diermeier, D. \& van Roozendaal, P. (1998). The Duration of Cabinet Formation Processes in Western Multi-Party Democracies. British Journal of Political Science 28: 609-626. 
Dumont, P. (2011) The Belgian Rainbow Coalition: Optical Illusion or Mechanical Phenomenon?. In R. B. Andeweg, L. De Winter \& P. Dumont (Eds). Puzzles of Coalition Formation. Coalition Theory and Deviant Cases. London: Routledge, pp. 165-189.

Duverger, M. (1950). L'Influence des Systèmes Électoraux sur la Vie Politique. Paris: Presses de la Fondation Nationale des Sciences Politiques.

Ecker, A. \& Meyer,T. M. (2020). Coalition Bargaining Duration in Multiparty Democracies. British Journal of Political Science 50(1): 1-20.

Gilley, B. (2006). The Meaning and Measure of State Legitimacy: Results for 72 Countries. European Journal of Political Research 45(3): 499-525.

Heylen, W., \& Van Hecke, S. (2008) Regeringen die niet regeren. Het malgoverno van de Belgische politiek. Leuven: Lannoo Campus.

Hooghe, L. Marks, G. \& Wilson, C. J. (2002). Does Left/Right Structure Party Positions on European Integration? Comparative Political Studies 35: 965-989.

Laakso, M., \& Taagepera, R. (1979). "Effective" Number of Parties: A Measure with Application to West Europe. Comparative Political Studies 12(1):3-27.

Lijphart, A. (1999). Patterns of Democracy. Yale, MI:Yale University Press.

Lorwin, V. R. (1971). Segmented Pluralism: Ideological Cleavages and Political Cohesion in the Smaller European Democracies. Comparative Politics 3(2): 141-175.

Lipset, S. M., \& Rokkan, S. (Eds.). (1967). Party Systems and Voter Alignments: Cross-National Perspectives. New York, NY: Free Press.

Magalhães, P. (2017). Economic Outcomes, Quality of Governance, and Satisfaction With Democracy. In C. van Ham, C., J. J. Thomassen, K. Aarts, \& R. B. Andeweg (Eds.). Myth and Reality of the Legitimacy Crisis: Explaining Trends and Cross-National Differences in Established Democracies. Oxford: Oxford University Press, pp. 156-171.

Müller W.C., \& K. Strøm (Eds.). (2000) Coalition Governments in Western Europe Oxford: Oxford University Press.

Müller, W. C., \& Strøm, K. (2008). Coalition Agreements and Cabinet Governance. In K. Strøm, W.C. Müller, \& T. Bergman (Eds.). Cabinets and Coalition Bargaining:The Democratic Life Cycle in Western Europe. Oxford: Oxford University Press, pp. 159-200.

Narud, H-M., \& Valen, H. (2008). Membership and Electoral Performance, In K. Strøm, W.C. Müller \& T. Bergman (Eds.). Cabinets and Coalition Bargaining: The Democratic Life Cycle in Western Europe. Oxford: Oxford University Press, pp. 369-402.

Reuchamps, M., Sinardet, D., Dodeigne, J., \& Caluwaerts, D. (2017). Reforming Belgium's Federalism: Comparing the Views of MPs and Voters. Government and Opposition: An International Journal of Comparative Politics 52(3): 460-482.

Sägesser, C. (2020). La formation du gouvernement De Croo (mai 2019-octobre 2020). Courrier hebdomadaire du CRISP 26: 5-86.

Siaroff, A. (2019). Comparative European Party Systems: An Analysis of Parliamentary Elections Since 1945. Oxon: Routledge.

Strøm, K. (1990). Minority Government and Majority Rule. Cambridge: Cambridge University Press.

Strøm, K. (1994). The Presthus debacle: Intraparty politics and bargaining failure in Norway. American Political Science Review 88(1): 112-127.

Strøm, K., \& Müller, W. C. (1999). The Keys to Togetherness: Coalition Agreements in Parliamentary Democracies. The Journal of Legislative Studies 5(3-4): 255-282.

Strøm, K., Müller, W. C., \& Bergman, T. (Eds.). (2008). Cabinets and Coalition Bargaining: The Democratic Life Cycle in Western Europe. Oxford: Oxford University Press. 
Taagepera, R., \& Grofman, B. (1985). Rethinking Duverger's Law: Predicting the Effective Number of Parties in Plurality and PR Systems - Parties Minus Issues Equals One European. Journal of Political Research 13(4): 341-352.

Tarek, B. A., \& Ahmed, Z. (2017). Institutional Quality and Public Debt Accumulation: An Empirical Analysis. International Economic Journal 31(3): 415-435.

van Ham, C., \& Thomassen, J. J. (2017). The Myth of Legitimacy Decline: An Empirical Evaluation of Trends In Political Support in Established Democracies. In van Ham, C., Thomassen, J. J., Aarts, K., \& Andeweg, R. B. (Eds.). Myth and Reality of the Legitimacy Crisis: Explaining Trends and Cross-National Differences in Established Democracies. Oxford: Oxford University Press, pp. 3-16.

Weatherford, M. S. (1992). Measuring Political Legitimacy. The American Political Science Review 86(1): 149-166. 